\title{
Further Observations on the Nutritive Value of the Proteins contained in Wheat Flours of Different Extraction Rates
}

\author{
By H. CHICK and E. B. SLACK \\ Lister Institute of Preventive Medicine, London, S.W. I
}

(Received 5 May 1948)

Chick (1942) described experiments in which comparison was made of the growthsupporting value of the proteins contained in flours of 100,85 and $70 \%$ extraction of the wheat grain, the method employed being that of Osborne, Mendel \& Ferry (1919). In these tests three groups of weanling litter-mate rats were fed ad lib. amounts of three different diets containing equal suboptimal amounts of protein provided by the respective flours, the protein being the factor limiting growth in an otherwise adequate regime. Determinations of the protein efficiency ratio (g. weight increase/g. protein consumed, henceforth referred to as the P.E.R.), for the proteins of the different flours indicated an advantage over the proteins of white flour of $17-26 \%$ for those of wholemeal, and of $13-16 \%$ for those of flours of $85 \%$ extraction.

The value of results yielded by this type of experiment had previously been criticized by Mitchell (1924) and others, and carefully appraised by Fixsen (1935) and by Barnes, Maack, Knights \& Burr (1945). The chief grounds for criticism were: that the method does not differentiate between the value of the protein for maintenance and for growth; that under conditions of $a d$ lib. feeding the diet containing the protein judged to be of higher nutritive value will probably be more palatable to the experimental animal and, for this reason rather than because of.its higher nutritive value, will be consumed in greater amount, with a consequently greater weight increase; that the weight gain of larger, more rapidly growing, animals will contain relatively more fat and, therefore, will not be a measure of the increase in body protein. The last objection is effectively answered in the accompanying paper by Slack (1948), at least in so far as the present experiments are concerned, and, in a recent review of the methods available for comparing the nutritive values of different proteins, Chick (1947) has replied to some of the other arguments. Barnes et al. (1945) concluded that fairly trustworthy results are given for the nutritive value of most proteins by P.E.R. values with ad lib. feeding if the protein content of the ration is $10-12 \%$. Graves (1945, 1946), however, in repeating the above criticisms, found a basis for discrediting the conclusion arrived at by Chick (1942) that proteins of whole wheat had a higher nutritive value than those of white flour.

The present paper presents additional evidence of the value of the method of Osborne $e t$ al. (1919) for comparing the nutritive efficiency of proteins in wheat by determining their P.E.R. In the first experiment (Exp. 1), of which a preliminary account has already been published (Chick, Copping \& Slack, I946), in addition to measurements of weight increase, food and nitrogen intake, faecal nitrogen and weight of faeces, 
determinations were also made of the proportion of the ingested nitrogen which was retained in the bodies of groups of comparable young rats fed on diets in which the protein was derived from flours of $70,80,85$ and $100 \%$ extraction, respectively. In order to do this, analyses were made of the composition of the bodies of the rats in the different groups at the end of the test and of comparable litter-mates killed at the beginning of the experiment. This work is fully reported in the accompanying paper by Slack (1948) and only the final results will be alluded to here. They show, however, a close correlation between the proportion of ingested nitrogen retained in the animal's body, the growth rate, and the P.E.R. values of the proteins of the different flours.

A second experiment (Exp. 2) of a different type is also reported in this paper. The results confirmed the superiority of the nutritive value of the proteins contained in the whole wheat over those of white flour. Equal rates of growth were obtained when the protein content of the diet containing the wholemeal flour was $25 \%$ lower than that of the diet containing the white flour.

\section{EXPERIMENTAL}

Exp. I. 'The flours (K series) were supplied by the Cereals Research Station, St Albans, and were all milled from the same grist. With the exception of the wholemeal flour they were prepared on a semi-commercial scale in I ton lots. Analysis revealed a nitrogen content, on the dry weight, of $2.55,2.52,2.42$ and $2.34 \%$ for the $100,85,80$ and $70 \%$ extraction flours, respectively. The flours were incorporated as the sole source of nitrogen in a series of four diets, adequate in other essential nutrients but suboptimal in protein content, which was about $12 \%$. The nitrogen content of the diets was equalized by the addition of pure maize starch to the fours of higher percentage extraction (see 'Table $\mathrm{I}$ ). The four diets were given to four groups of six rats

\section{Table r. Percentage composition in terms of dry ingredients of diets} used in Exps. I and 2

\begin{tabular}{|c|c|c|c|c|c|c|c|c|c|c|}
\hline & & & Exp. 1 & Series & flours & & $E_{x_{1}}$ & 2. Ser & ies $G$ flo & \\
\hline & gredient & $\begin{array}{c}\text { Nitrogen } \\
\text { content } \\
(\%)\end{array}$ & Diet 1 & Diet 2 & Diet 3 & Diet 4 & $\begin{array}{c}\text { Nitrogen } \\
\text { content } \\
(\%)\end{array}$ & Diet 5 & Diet 6 & Diet 7 \\
\hline Flour & 70 & $2 \cdot 34$ & 92 & 8 & - & - & $2 \cdot 27$ & 92 & - & - \\
\hline$\%$ extrac- & $\begin{array}{l}80 \\
85\end{array}$ & $\begin{array}{l}2 \cdot 42 \\
2 \cdot 52\end{array}$ & - & 88 & 85 & $\begin{array}{l}-- \\
--\end{array}$ & - &.- & $\bar{z}$ & - \\
\hline & 100 & 2.55 & - & - & - & 85 & $2 \cdot 44$ & $\ldots$ & $78 \cdot 3$ & 62 \\
\hline Maize star & & 0.03 & - & $3 \cdot 7$ & $6 \cdot 8$ & $6 \cdot 8$ & 0.03 & - & $I_{4}$ & 30 \\
\hline Arachis oil, & hardened & - & $4 \cdot 6$ & $4 \cdot 6$ & $4 \cdot 6$ & $4 \cdot 6$ & - & 4 & 4 & 4 \\
\hline Salt mixtur & & - & 2 & 2 & 2 & 2 & $\dot{-}$ & 2 & 2 & 2 \\
\hline Cod-liver o & & - & I & I & I & $\mathbf{I}$ & - & I & I & I \\
\hline $\begin{array}{l}\text { Average nit } \\
\text { tent of die }\end{array}$ & $\begin{array}{l}\text { rogen con- } \\
t(\%)\end{array}$ & - & $2 \cdot 10$ & $2 \cdot 11$ & $2 \cdot 08$ & 2.08 & -- & 1.99 & $I \cdot 9 I$ & $\mathrm{I} \cdot 53$ \\
\hline
\end{tabular}

- McCollum, Simmonds \& Pitz (r9r7). 
each, selected from four newly weaned litters to give groups comparable in heredity, sex and initial body-weight. The rats were caged and fed singly but in other ways each group was treated as a unit, estimations being made of total dry food and nitrogen consumed and of the total faeces and faecal nitrogen passed by the group. Further details of the methods used were published by Chick (1942).

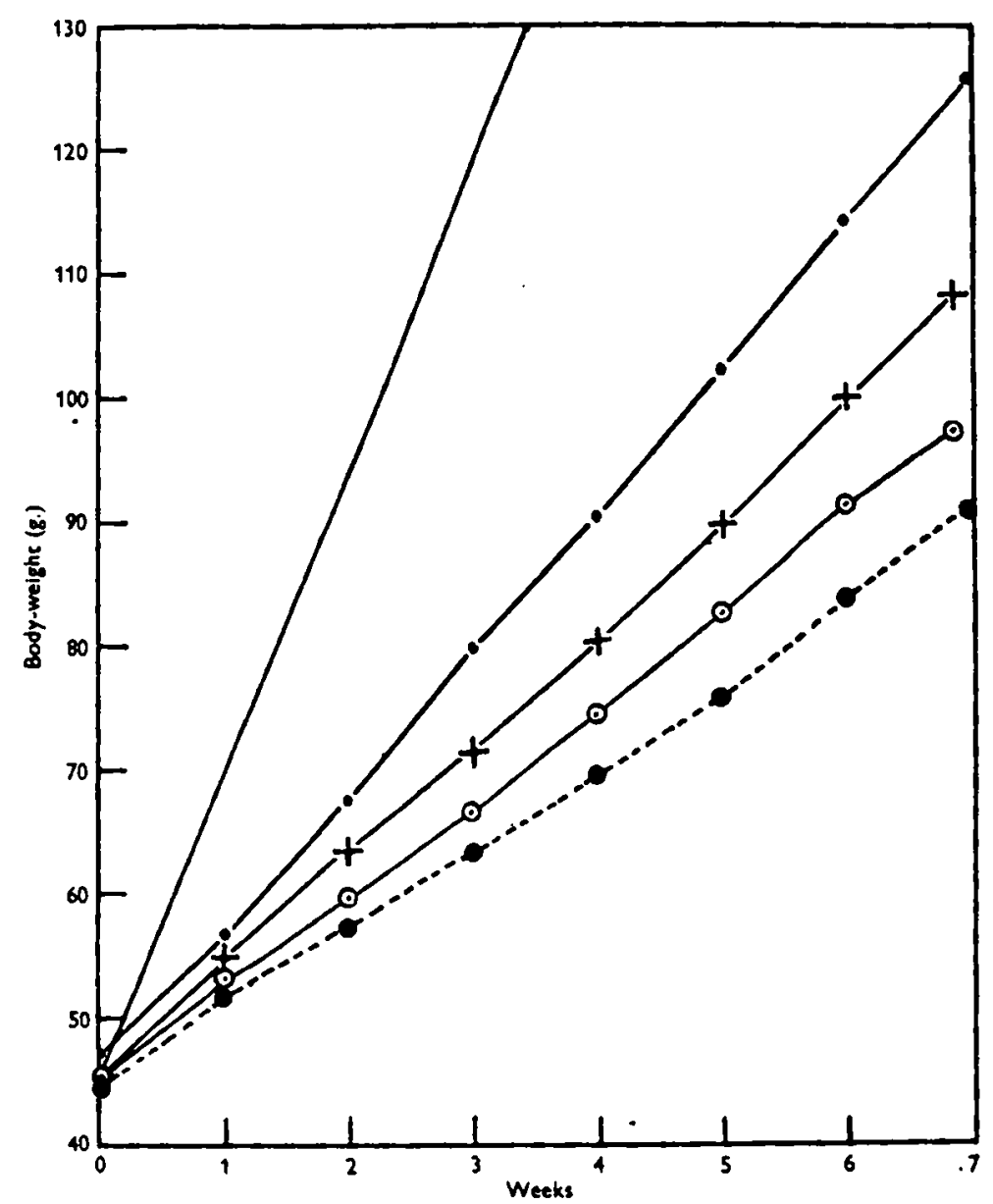

Fig. I. Exp. x. Average weight curves for groups of six rats maintained on diets in which the nitrogen, c. $2 \cdot 1 \%$ of the dry weight, was derived from flour of $700 \ldots, 800-0,85+-+$ and $100 \%$

— 'Normal' growth curve of similar rats fed on a complete synthetic diet containing $25 \%$ casein.

The results set out in Table 2 show that the flours formed a descending series in respect of the nutritive value of their proteins which corresponded to the progressive fall in the extraction rate. In Fig. $\mathbf{I}$ is shown the average increase of weight of the rats in the different groups. At the end of the 7 weeks' test the rats receiving the wholemeal diet had attained an average body-weight of $126 \mathrm{~g}$.; the corresponding weights for the groups receiving the 85,80 and $70 \%$ extraction flours were 110,99 and 91 g., respectively. In addition it was noticeable that the rats receiving the wholemeal and 
$85 \%$ flours were in a better and healthier condition than the others, as judged by the condition of their coats, eyes and muscular development. As was to be expected, the more rapidly growing animals had better appetites than their outstripped litter-mates and consumed more food, but comparison of intake with growth showed that they used it more economically.

The values for the P.E.R. of the proteins in the wholemeal, 85,80 and $70 \%$ extraction flours were respectively $\mathrm{I} \cdot 63, \mathrm{r} \cdot 63, \mathrm{r} \cdot 47$ and $\mathrm{r} \cdot 35$. If the P.E.R. values were calculated on the basis of the proteins absorbed from the different flours, the advantage shown by the 100 and $85 \%$ extraction flours would appear even greater owing to the lesser availability of their proteins. In the last three columns of Table 2 are given figures taken from the paper by Slack (1948) which show for the different flours the average proportion of the nitrogen eaten which was incorporated in the bodies of the rats during the period of the test. The figures were $26.7 \%$ for the wholemeal nitrogen and $22.9 \%$ for that of the white flour of $70 \%$ extraction; the corresponding figures for the proportion of the absorbed nitrogen which was retained were 33 and $25.9 \%$. In capacity to support growth, in P.E.R. value and in the proportion of ingested nitrogen retained, the proteins of the 70 and $80 \%$ extraction flours fall into a group of about the same order; those of the wholemeal flour were in all respects more efficient and those of the $85 \%$ extraction flour were intermediate.

The apparent digestibility of the nitrogen in the four flours was found to fall progressively as the percentage extraction was increased; the coefficients determined for the flours of $70,80,85$ and $100 \%$ extraction were $88 \cdot 8,86.7,85.5$ and $81 \cdot 0$ respectively.

Exp. 2. The comparison of the nutritive value of the proteins of wholemeal and $70 \%$ extraction white flour made in the preceding experiment by comparing the values for their respective P.E.R. showed a superiority of the former of about $20 \%$. It therefore seemed possible that diets of equal growth-supporting power might be obtained with proteins supplied respectively from wholemeal and white flour if the proportion of the protein in the first were about $20 \%$ lower than that in the second. Exp. 2 was designed to test this possibility and the result showed it to be realized.

The performance of young weanling rats on diet 5 (Table $\mathrm{r}$ ), containing white-flour protein at a level yielding $2 \%$ of nitrogen on dry weight, was compared with that of litter-mates on two diets, 6 and 7 , in which the protein was supplied from wholemeal flour and the nitrogen content on dry weight was respectively $I \cdot 9$ and $I .5 \%$. Unfortunately the supply of the $\mathrm{K}$ series of flours used in Exp. I was insufficient for this test and use had to be made of another (series G), the wholemeal flour of which had a nitrogen content of $2 \cdot 44 \%$ and the white flour one of $2 \cdot 27 \%$, on dry weight. The composition of diets 5,6 and 7 , which were made according to the ordinary procedure, is given in Table $\mathrm{I}$.

Three litters of newly weaned rats were distributed evenly in three groups of seven rats each, receiving respectively diets 5,6 and 7 . The experiment lasted 6 weeks. The intake of food was measured weekly. The faeces were collected and analysed for nitrogen content in fortnightly periods and thus three checks were provided of the digestibility of the nitrogen in the different diets. Average growth curves of the rats 


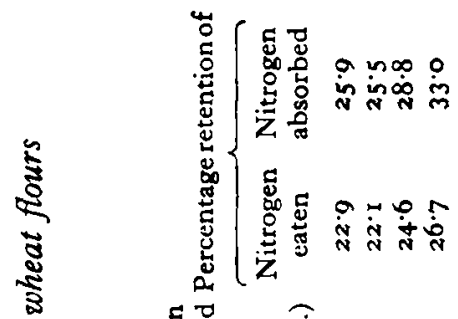

है

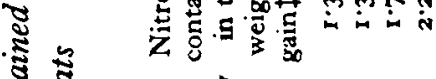

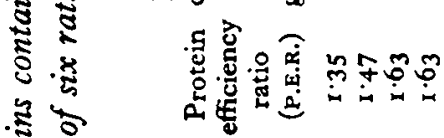

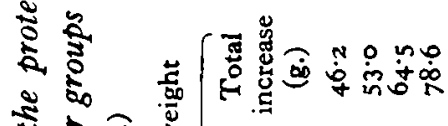

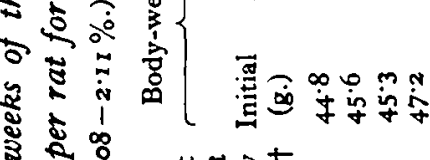

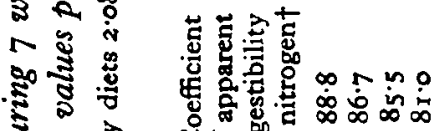

홍

พับ

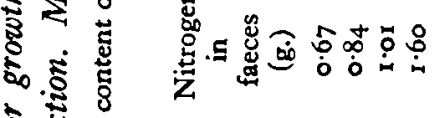

5

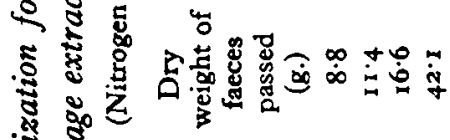

ฐ

s.

害密

$\therefore$

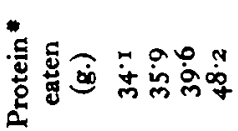

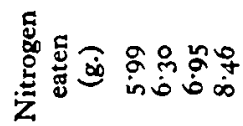

离

i

लำ

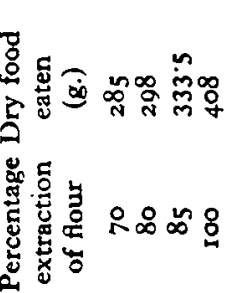

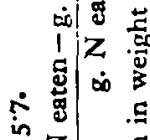

in

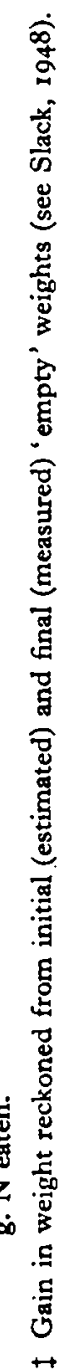

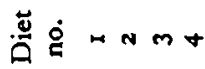

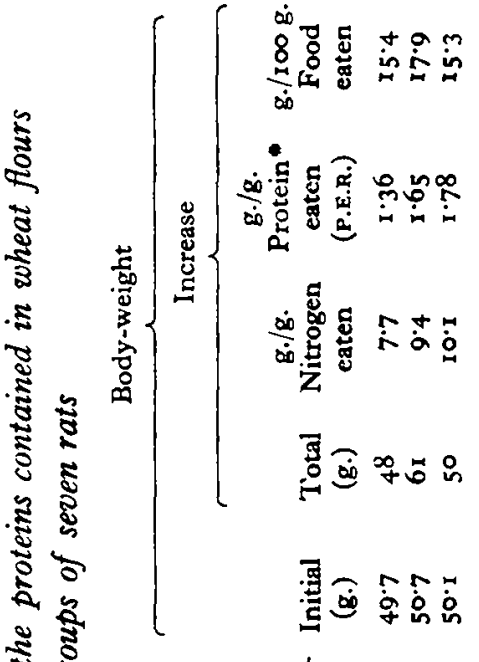

के

उั

$\circ$

है

急

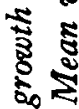

s.

돈

촐

ริㅇำ

$\therefore \circ$

害弯

웝용

i

究

$\dot{m}$

Fi

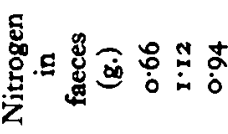

4

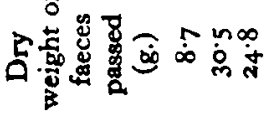

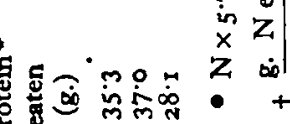

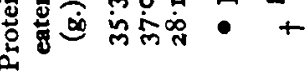

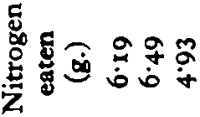

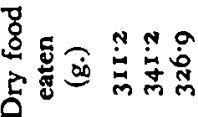

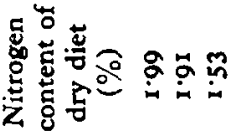

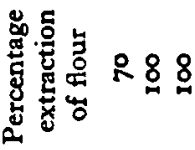

产宗的人 
in the three groups are shown in Fig. 2, and figures for intake of food and nitrogen and excretion of nitrogen in the faeces are given in Table 3 .

The results showed an almost identical performance by the rats on the white-flour diet 5 containing $\mathbf{r} \cdot 99 \%$ nitrogen and by those receiving the wholemeal diet 7

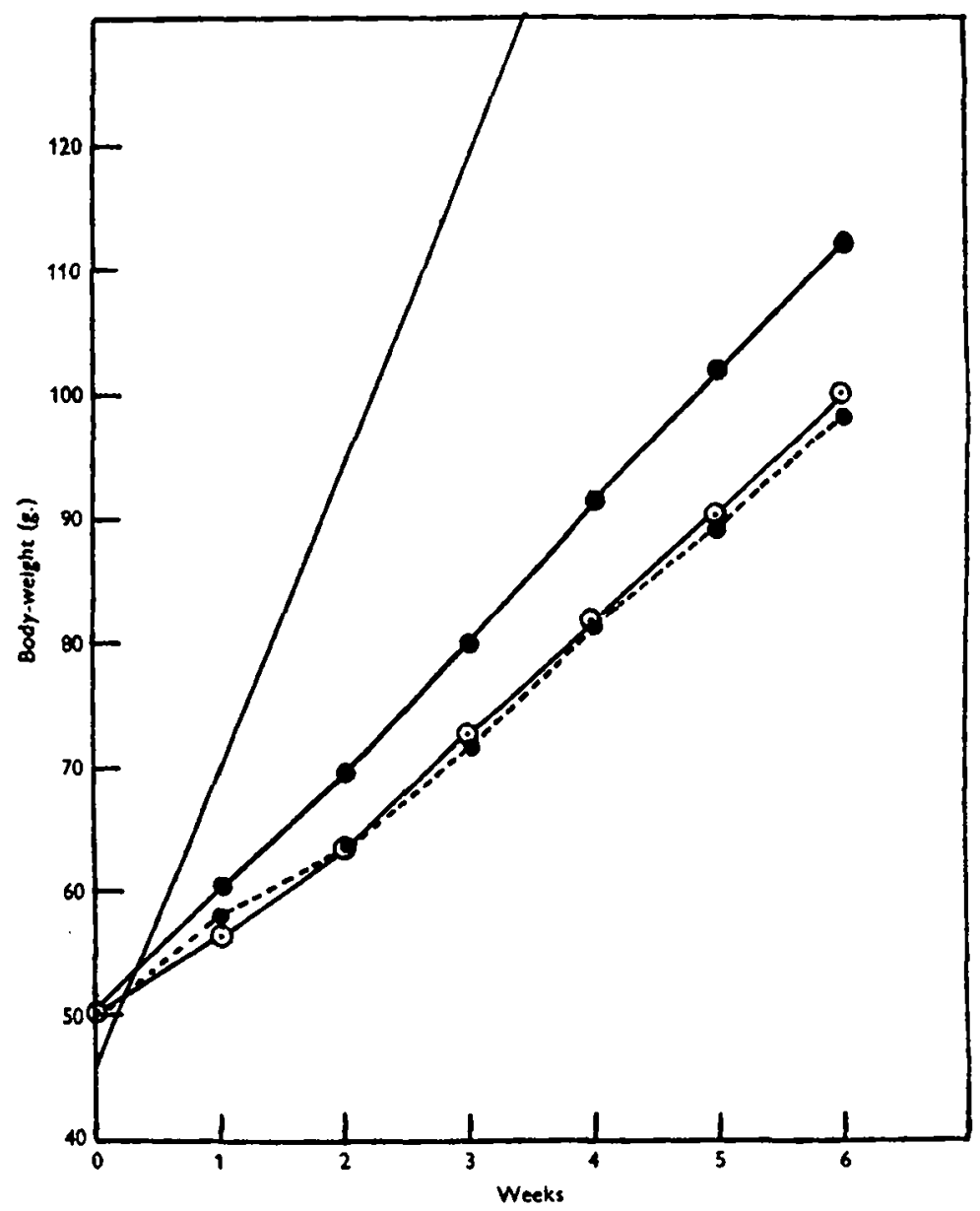

Fig. 2. Exp. 2. Average weight curves per rat for groups of six rats maintained on diets in which the nitrogen was derived from flour of : $70 \%$ extraction providing $1.99 \%$ nitrogen on dry weight of diet $\bullet-.-\bullet, 100 \%$ extraction providing $1.53 \%$ nitrogen on dry weight of diet $\odot-\bigcirc$, and $100 \%$ extraction providing $1.91 \%$ nitrogen on dry weight of diet

'Normal' growth curve of similar rats fed on a complete synthetic diet containing $25 \%$ casein.

containing $\mathrm{I} \cdot 53 \%$ nitrogen, about $25 \%$ less protein of a lower degrec of digestibility. The average food intake per rat on these two diets was 3 I I and $327 \mathrm{~g}$., the total weight increases 48 and $50 \mathrm{~g}$., and the coefficients of digestibility of the nitrogen 89.3 and 80.7 respectively. These figures for digestibility are in close agreement with those (88.8 and $8 \mathrm{I} \cdot 0$ respectively) obtained in Exp. I for that of the nitrogen in 70 and $100 \%$ extraction flours.

From these results one may conclude that the proteins of the wholemeal flour had 
a nutritive efficiency $25 \%$ greater than that of the white-flour proteins, a result which confirms that of Exp. I. Comparison of the P.E.R. would seem to indicate an even greater advantage for the wholemeal proteins, but this conclusion would be unjustified, as one of the conditions for determining P.E.R. is that the proteins under test should be given in diets of equal protein content. It is, however, permissible to compare the value of the P.E.R., $I \cdot 36$, obtained with diet 5 of nitrogen content $x \cdot 99 \%$, with that of $x \cdot 65$ obtained with diet 6 of nitrogen content $\mathrm{I} \cdot 9 \mathrm{I} \%$. These figures show an advantage of $21 \%$ for the wholemeal proteins, a result which is in agreement with that derived from the tests with diets 5 and 7 by a different type of experiment. In those tests comparison is made between the different proportions in the diets of white-flour proteins and of wholemeal proteins, respectively, which correspond to an equal growth performance; from the results obtained with diets 5 and 6 comparison is made between the values of P.E.R. obtained with diets containing the same proportion of protein derived, respectively, from the two flours.

\section{DISCUSSION}

The nutritive advantage demonstrated for the proteins in flours of higher, over those of lower, percentage extraction of the wheat grain is due to the fact that the proteins contained in the tissues of the outer layers of the grain, which include the aleurone, are of better quality than those situated in the endosperm. They are richer in the essential amino-acids lysine, arginine and tryptophan (Jones \& Gersdorff, 1925; Barton-Wright $\&$ Moran, r946). The results of tests of the growth-promoting value for young rats of the proteins of white flour alone and of admixtures with those of wheat bran showed an advantage for the latter which was in direct proportion to the amount of bran proteins in the mixture, in other words to the amount of extra lysine (or tryptophan) introduced with the bran (Chick, Cutting, Martin \& Slack, 1947). The bran is included in the fractions of the wheat discarded in the milling of white flour; these fractions comprise, besides the fibrous pericarp, the aleurone layer, the germ and the outer portions of the endosperm. The aleurone layer, although only one cell thick, occupies from 7.5 to $9 \%$ of the volume of the grain and has a protein content of about $22 \%$, amounting to about $16 \%$ of the total protein in the grain (Girard, 1884; Osborne \& Mendel, 1919; Booth, Carter, Jones \& Moran, I94 I ; Hinton, 1947; Chick et al. 1947). Also the outer layers of the endosperm are richer in protein than the inner portion and the protein has a higher nutritive value (Cobb, 1905; Morris, Alexander \& Pascoe, 1945; Moran, 1945; Moran \& Drummond, 1945; Hinton, 1947; Chick et al. 1947). The germ is even richer in protein of high quality, but as its weight is only about $1 \cdot 5-2 \cdot 5 \%$ of that of the grain, its contribution of protein is relatively small. As the percentage extraction of the flour is progressively raised, more and more of these outer tissues richer in protein of higher nutritive value are included.

At $80 \%$ extraction the flour resembled that of $70 \%$ extraction in consisting almost exclusively of endosperm, but it contained more of the outer layers (see Cobb, 1905), a fact which was reflected in its higher growth-promoting power and higher P.E.R. value; the proportion of the ingested nitrogen retained was not, however, any greater 
(see Table 2). At $85 \%$ extraction the flour contains, besides the outer endosperm, some of the germ, a fair proportion of the aleurone and relatively little of the pericarp. The nutritive advantage shown over the $80 \%$ flour is probably due to the amount of the aleurone it contains. The separation of the aleurone in amounts sufficient for a biological test has not been accomplished, but fractions rich in this tissue have been shown to favour retention of nitrogen when compared with white flour in tests on rats and on human subjects (Guillemet \& Jacquot, I944; Jacquot, Trémolières, Guillemet \& Erfman, 1944).

Flour of $85 \%$ extraction produces an acceptable loaf which is off-white in colour. In 1942 it was selected by the authorities in this country as National wartime flour for ordinary bread making.

\section{SUMMARY}

1. Four groups of rats from the same litters were maintained for 7 weeks on diets containing equal amounts of protein derived from wheat flours of $70,80,85$ and $100 \%$ extraction of the grain respectively. The diets were adequate in other essential nutrients, but the proportion of protein was suboptimal, about $12 \%(\mathrm{~N} \times 5.7)$ on dry weight.

2. The average rates of weekly weight increase in the four groups were respectively $6 \cdot 6,7 \cdot 6,9 \cdot 2$ and $I \times \cdot 3 \mathrm{~g}$.; the corresponding values of the P.E.R. (g. weight increase/g. protein consumed) were $1 \cdot 35,1 \cdot 47,1 \cdot 63$ and $1 \cdot 63$. The percentage of the nitrogen ingested which was incorporated in the bodies of the rats during the period of the test were respectively $22 \cdot 9,22 \cdot 1,24 \cdot 6$ and $26 \cdot 7 \%$.

3. Equal rates of weight increase were observed when rats consumed approximately equal amounts of diets, otherwise similarly composed but containing respectively $\mathbf{I} \cdot 53 \%$ nitrogen derived from whole wheat (100\% extraction) flour, and $\mathrm{I} \cdot 99 \%$ nitrogen derived from white flour of $70 \%$ extraction. This result showed a $25 \%$ inferiority in efficiency for supporting growth, of the proteins in the white flour. The P.E.R. calculated from this experiment for the proteins of the white flour was $1 \cdot 36$ : for those of whole-wheat proteins in a similar diet containing $1.91 \%$ nitrogen it was I. $65 \%$.

4. From the results summarized in 2 and 3 above, it may be concluded that the nutritive efficiency for support of growth in young rats, as measured by the value of the P.E.R., is about $20 \%$ greater for the proteins of whole-wheat flour than for those of white flour of $70 \%$ extraction. The value of the proteins in the specimens of $85 \%$ extraction flour investigated, as judged by the same criterion, was equal to that of the whole-wheat proteins; the value of those of the $80 \%$ extraction flour was much lower and nearer to that of those in the flour of $70 \%$ extraction.

5. The figures found for the coefficients of apparent digestibility of the nitrogen in the flours of $70,80,85$ and $100 \%$ extraction were respectively $88 \cdot 8-89 \cdot 3,86.7,85.5$ and $80.7-81 \cdot 0 \%$. The lower digestibility of the nitrogen in the flours of higher percentage extraction was more than compensated by their greater nutritive value.

Our thanks are due to the Cereals Research Station, St Albans, and particularly to Dr T. Moran, for the supply of the specially milled flours used in this work; also to 
Mr G. W. Flynn for assistance in the care of the experimental animals. We wish to acknowledge also the hospitality of Sir Charles Martin at Roebuck House, Cambridge, where the work was carried out.

\section{REFERENCES}

Bernes, R. H., Maack, J. E., Knights, M. J. \& Burr, G. O. (1945). Cereal Chem. 22, 273. Barton-Wright, E. C. \& Moran, T. (1946). Analyst, 71, 278.

Booth, R. G., Carter, R. H., Jones, C. R. \& Moran, T. (r94I). Chem. E® Ind. 60, 903.

Chick, H. (1942). Lancet, 242, 405.

Chick, H. (1947). Chem. Ef Ind. 66, 318.

Chick, H., Copping, A. M. \& Slack, E. B. (1946). Lancet, 250, 196.

Chick, H., Cutting, M. E. M., Martin, C. J. \& Slack, E. B. (1947). Brit. F. Nutrit. 1, 16r.

Cobb, N. A. (1905). Misc. Publ. Dep. Agric. N.S.W. no. 539.

Fixsen, M. A. B. (1935). Nutr. Abstr. Rev. 4, 447.

Girard, A. (1884). Ann. Chim. (Phys.), ser. vi, 3, 289.

Graves, H. C. H. (1945). Chem. EF Ind. 64, 146 .

Graves, H. C. H. (1946). Chem. E Ind. 65, 26 r.

Guillemet, R. \& Jacquot, R. (1944). Bull. Soc. Chim. biol., Paris, 26, 324.

Hinton, J. J. C. (1947). Proc. roy. Soc. B, 134, 418.

Jacquot, R., Trémolières, J., Guillemet, R. \& Erfman, R. (1944). Bull. Acad. Med. Paris, nos. $31-2$, p. 608 .

Jones, D. B. \& Gersdorff, C. E. F. (1925). F. biol. Chem. 64, 24 I.

McCollum, E. V., Simmonds, N. \& Pitz, W. (1917). F. biol. Chem. 29, 52 1.

Mitchell, H. H. (1924). Physiol. Rev. 4, 24.

Moran, T. (1945). Nature, Lond., 155, 205.

Moran, T. \& Drummond, J. C. (1945). Lancet, 248, 698.

Morris, V. H., Alexander, T. L. \& Pascoe, E. D. (1945). Cereal Chem. 22, 351.

Osborne, T. B. \& Mendel, L. B. (1919). F. biol. Chem. 37, 557.

Osborne, T. B., Mendel, L. B. \& Ferry, E. L. (1919). $\mathscr{F}$. biol. Chem. 37, 223.

Slack, E. B. (1948). Brit. F. Nutrit. 2, 214. 